training of Sudanese students for all departments of the professional life of their country. This will allow for increased 'dilution'.

These are all wonderful developments in a land which counts its modern history from only forty-five years ago. We can only regret that Sir Douglas Newbold, who died in March as the result of an accident, did not live to watch the progress which he did so much to promote and foster.

\title{
Planning in Northern Rhodesia
}

According to the tentative views of Mr. C. F. Clay, the Adviser on Development, which were submitted to the government of Northern Rhodesia last February, both Europeans and Africans will have their parts to play in the future. Some of the proposals needed further examination, but with regard to others the government expressed general agreement in April and undertook to apply for the necessary grants from the Colonial Development and Welfare Fund. This acceptance applies in particular to the plans for Development Centres and to these we now limit our exposition. Leaving aside the Kaonde-Lunda province in the north-west, five centres are to be chosen for their suitability to serve zones in which social and ecological conditions are relatively uniform. At each Centre there will be a roo-bed hospital; a normal school; a combined agricultural and veterinary research station, which will later serve as a stock-farm for multiplication and distribution of improved crops and stock; a model community centre with Native Treasury, Native Court and central village school; a butcher's shop and various craftsmen's shops; and an area of land embracing not less than a group of six family holdings will be laid out in accordance with the latest views of the Centre concerning planned development of village lands. The buildings to be erected will be of the simplest type. The staff at each Centre will comprise six Europeans, including (2) medical, agricultural, veterinary, and education officers and a senior District Officer in charge; there will also be a subordinate European staff of three nursing sisters and health, agricultural and livestock inspectors. At a later stage technical instructors are to be appointed to experiment in the development of village industries-in the Barotse centre such an instructor will be appointed from the first: it is not clear why the other Centres will have to wait. Associated with each Centre there are to be four or five native authority areas under the control of the team at the Centre; the nature of this 'control' is not stated, but they will be demonstration areas in which accelerated development will be stimulated. Without attempting a rigid definition of the matters with which the Centres will be concerned the plan specifies housing, sanitation, diet, child welfare and maternity work, mass education, development of a system of local government in step with the social and economic development that is being planned, and local marketing systems. The Centres are to be lighthouses radiating the beams of civilization over the whole territory. At each Centre training will be given to African medical orderlies for village dispensaries, village schoolmasters and rural assistants. The last-named will receive training in all the practical aspects of a sound and healthy rural life, the design and construction of improved housing, \&c. These men will be posted to local centres in teams of three at the conclusion of their training; in ten years it is hoped that 1,570 such centres will be fully staffed, one centre for each thousand of the African population.

Who, it may be asked, is to see that the work of the trained Africans at the local centres is carried on efficiently? Apparently the necessary inspection and supervision will not be done by the officers at the Centres. A number of secondary Development Teams, directed by Provincial Teams of high-grade staff, will be established for this purpose. Joint planning by the Provincial Teams will be directed to such features of development as rural water-supplies. Special projects, such as anti-tsetse schemes, demanding specialist knowledge, will remain in the hands of the technical departments. 
It is proposed that a Native Development and Welfare Council be constituted to take the place of the present Native Development Board; its duty will be to examine, collate, and advise on all schemes. It will act largely through eight standing committees. Two members of the Legislative Council, two representatives of the Missions, and the Director of the Rhodes-Livingstone Institute will be among the twelve members.

On paper this is a magnificent scheme; if carried out it will transform Northern Rhodesia. It may be called a scheme for the establishment of secular mission stations all over the territory. It is not clear from the Memorandum what part is to be played by the Christian Missions which have hitherto borne the burden (latterly with government assistance) of education: how are they to fit in? It is indeed proposed to 'rationalize' teacher training by concentrating into five government normal schools at the Centres the twenty-odd Mission normal schools. 'Certain difficulties have prevented the immediate acceptance of this suggestion, but the question is being further considered.' 'The plan, however, allows for two Mission representatives on the staff of each normal school at the Centres. These, as in regard to the other members of the subordinate staff, are to be temporary and will be replaced by Africans: whether these Africans would be 'Mission representatives' is not stated. Nothing is said about the mission schools which may have been already planted at any of the future $\mathrm{r}, 57^{\circ}$ local centres. The place of religion in education, insisted on by Mr. Scott in this number, is passed over in silence.

\section{Soil Erosion and Land Use in South Africa}

The Government of the Union of South Africa wisely called in Dr. Hugh H. Bennett, Chief of the Soil Conservation Service of the United States Department of Agriculture, to advise on the most serious problem confronting them. We use the words 'most serious' deliberately. For should present conditions continue unchecked at the same rate as now South Africa would become a Sahara; and what will then matter social services, colour bars, or anything else? There is plenty of talk about raising the standard of living, of improving nutrition and health, all of which necessary reforms call for more food and better food; but if the land goes out of production-what then? 'There can be no permanence to agriculture anywhere without permanently productive soil, and without a permanent agriculture there cannot be anywhere on earth any assurance whatever of a permanent nation. ... Soil conservation is concerned with the base of human and national welfare.' In these words Dr. Bennett utters a truism which still needs to be hammered home, and not in South Africa only. He did not see the whole of South Africa during his visit of two months, but the principal regions of intensive and semi-intensive farming were covered in some detail. The Transkei, as well as Swaziland and Basutoland, was included in his itinerary. The grim fact that faces the Union is that millions of acres in both European and African areas have been affected (in various degrees of intensity) by erosion: fertility of the soil has thereby been reduced by 25 per cent. and 'probably a few decades more of the careless land-use now unfortunately prevailing will take away so per cent. of the remaining fertility of the country '. In the northern Transvaal it is estimated that more than roo,000 acres of formerly productive land, more or less in a solid block, have lost practically all the original top-soil and are worn down to sub-soil that assumes the hardness of rock during the dry season. The ill-effects of continuing erosion are accumulative. South Africa is drying up on a large scale; and the dessication is due in no small degree to man's action. Dongas and sheetwashing affect springs and wells; streams that formerly ran at lively rates are now dry as a result of destroying vegetation in their headwater areas. Soil swept off by water silts up the dams: ' most of South Africa's reservoirs are filling with sediment.' Erosion and exhaustive cropping have altered the type of vegetation on hundreds of thousands of acres, poisonous plants taking the place of pasture. 